\title{
Grafting efficiency in Brazilian native tree species
}

\section{Eficiência da enxertia em espécies arbóreas nativas brasileiras}

\author{
Gleidson Guilherme Caldas Mendes ${ }^{1}$ (D), Gleison Augusto dos Santos ${ }^{1}$ (1), Aloísio Xavier ${ }^{1}$ (1), \\ Sebastião Venâncio Martins ${ }^{1}$ (D), Genaina Aparecida de Souza ${ }^{3}$ (D), Thales Guilherme Vaz Martins ${ }^{1}$ (D), \\ Raul Firmino dos Reis Neto ${ }^{2}$ (1) \\ ${ }^{1}$ Universidade Federal de Viçosa - UFV, Viçosa, MG, Brasil \\ ${ }^{2}$ Vale S.A., Brumadinho, MG, Brasil
}

How to cite: Mendes, G. G. C., Santos, G. A., Xavier, A., Martins, S. V., Souza, G. A., Martins, T. G. V., \& Reis Neto, R. F. (2021). Grafting efficiency in Brazilian native tree species. Scientia Forestalis, 49(132), e3687.

https://doi.org/10.18671/scifor.v49n132.04

\begin{abstract}
Vegetative propagation by grafting has been widely used to induce early flowering and fruiting in perennials. This study aimed to evaluate the grafting efficiency of seven native tree species in Brazil: Jacaranda mimosifolia, Handroanthus heptaphyllus, Swietenia macrophylla, Schinus terebinthifolius, Cariniana estrellensis, Poincianella pluviosa, and Hymenaea courbaril. The experiment was conducted from January to April 2018. Graft survival, shoot number, length, and circumference were determined at 50 and 90 days after grafting. Data were subjected to analysis of variance (ANOVA) followed by Tukey's test. Graft survival differed significantly between species. The highest survival rates were observed for J. mimosifolia, H. heptaphyllus, S. terebinthifolius, and S. macrophylla. Shoot length and circumference were higher in C. estrellensis and S. macrophylla, respectively. S. terebinthifolius and C. estrellensis had the highest shoot number, not differing from each other. These results indicate that the processes of scion/rootstock attachment, callus formation, and vascular tissue development were successful. Vegetative propagation of the studied tree species via grafting is effective and has good prospects for genotypes' rescuing of and for hybridization.
\end{abstract}

Keywords: Genetic breeding; Clonal orchard; Clonal propagation; Genetic conservation.

\section{Resumo}

A propagação vegetativa por enxertia tem sido amplamente utilizada para induzir floração e frutificação precoces em plantas perenes. O objetivo deste estudo foi avaliar a eficiência da enxertia de sete espécies arbóreas nativas do Brasil: Jacaranda mimosifolia, Handroanthus heptaphyllus, Swietenia macrophylla, Schinus terebinthifolius, Cariniana estrellensis, Poincianella pluviosa e Hymenaea courbaril. O experimento foi conduzido de janeiro a abril de 2018. A sobrevivência do enxerto, número de brotações, comprimento e circunferência foram determinados aos 50 e 90 dias após o enxerto. Os dados foram submetidos à análise de variância (ANOVA) seguida pelo teste de Tukey. A sobrevivência do enxerto diferiu significativamente entre as espécies. As maiores taxas de sobrevivência foram observadas para J. mimosifolia, $H$. heptaphyllus, S. terebinthifolius e S. macrophylla. O comprimento e a circunferência das brotações foram maiores em C. estrellensis e S. macrophylla, respectivamente. S. terebinthifolius e C. estrellensis apresentaram o maior número de brotações, não diferindo entre si. Esses resultados indicam que os processos de fixação de enxerto/porta-enxerto, formação de calos e desenvolvimento de tecido vascular foram bem-sucedidos. A propagação vegetativa das espécies arbóreas estudadas por meio de enxertia é eficaz e tem boas perspectivas de resgate de genótipos e hibridação.

Palavras-chave: Melhoramento genético; Pomar clonal; Propagação vegetativa; Conservação genética.

Financial support: This study was financed in part by the Coordenação de Aperfeiçoamento de Pessoal de Nível Superior - Brasil (CAPES) - Finance Code 001. Conflict of interest: Nothing to declare.

Corresponding author: gmendesflorestal@gmail.com

Received: 1 March 2021.

Accepted: 28 April 2021.

Editor: Paulo Henrique Müller Silva. (c) This is an Open Access article distributed under the terms of the Creative Commons Attribution License, which permits unrestricted use,
distribution, and reproduction in any medium, provided the original work is properly cited. 


\section{INTRODUCTION}

In recent years, the use of forest resources obtained from native tree species has increased in Brazil, generating revenue for the country. However, few efforts have been devoted to the planting of native trees (Morais et al., 2012). There are still many barriers to reforestation with native tree species in Brazil, such as lack of knowledge about their ecology, potential use, production technologies, management, silvicultural techniques, and productive genotypes (Stuepp et al., 2018).

Genetic improvement of perennials is a continuous and extensive process, comprising many cycles of selection and recombination. The process can take up to 18 years in Eucalyptus spp. individuals (Pires et al., 2011) and from 20 to 25 years for rubber trees (Hevea brasiliensis Müll.Arg.) (Gonçalves et al., 1990). Accelerating the generation turnover is an important strategy to increase genetic gain per unit time (Almqvist, 2013).

One way to accelerate the transition to the adult phase is by using vegetative propagation and growth regulators. These techniques are widely used in forestry. In Brazil; vegetative propagation has been successfully used to establish high-productivity forests in areas with the use of limited genetic material (Bandeira et al., 2006).

Advances are needed in vegetative reproduction strategies for the conservation and multiplication of high-quality germplasm. Grafting is a technique by which two different plant tissues are joined to originate a new individual (Rouphael et al., 2010; Almqvist, 2013). This type of vegetative propagation is used in clonal orchards for the production of improved seeds; it allows expansion of the genetic base through selection and recombination of genotypes (Moncur \& Hasan, 1994; Moraes et al., 2012).

The main advantages of grafting are early flowering and smaller crowns, which facilitates pollen collection, pollination, and seed harvesting (Rocha et al., 2002). The technique has been successfully used for various tree crops, including slash pine (Pinus elliottii Engelm.) (Parker et al., 1998), thale cress (Arabidopsis thaliana (L.) Heynh.) (Flaishman et al., 2008), sacha inchi (Plukenetia volubilis L.) (Cachique et al., 2018), and white gum (Eucalyptus dunnii Maiden) (Moraes et al., 2012).

Grafting is recommended to induce early flowering in tropical species. However, in Brazil, grafting of native trees is still incipient. The objective of this study was to evaluate the response of seven native tree species to grafting and their potential for use in hybridization programs.

\section{MATERIALS AND METHODS}

\section{Environmental Conditions}

The experiment was conducted in Viçosa, Minas Gerais, Brazil, from January to April 2018. Viçosa $\left(20^{\circ} 45^{\prime} \mathrm{S} 42^{\circ} 51^{\prime} \mathrm{W}\right)$ is located in the Zona da Mata region (coastal rainforest), at an elevation of $652 \mathrm{~m}$. The local climate is humid subtropical (Cwb in the Köppen classification), with an average annual rainfall of $1,185 \mathrm{~mm}$ and relative air humidity of about $80 \%$. The average annual temperature is $22.31^{\circ} \mathrm{C}$, with an average maximum of $28.2^{\circ} \mathrm{C}$ and an average minimum of $16.4^{\circ} \mathrm{C}$.

\section{Plant Material}

Rootstocks were grown from seeds. Seedlings of Jacaranda mimosifolia D.Don, Handroanthus heptaphyllus (Vell.) Mattos, Swietenia macrophylla King, Schinus terebinthifolius Raddi, Cariniana estrellensis (Raddi) Kuntze, Poincianella pluviosa (DC.) L.P.Queiros, and Hymenaea courbaril $\mathrm{L}$ were cultivated in $5 \mathrm{~L}$ polyethylene bags, fertilized with $40 \mathrm{~g}$ of Polyblen ${ }^{\circledR}$, and watered every 2 days during the 4 months prior to grafting. At the time of grafting, the seedlings were 1 year old, about $54 \mathrm{~cm}$ in height, and $5 \mathrm{~cm}$ in circumference.

Scions with a minimum of two buds were collected from the upper third of trees in the reproductive phase and in good health and vigor. Forty scions were obtained per species. Collections were performed at rural sites near Viçosa, Brazil. Cuttings were wrapped in moist 
paper towels, covered with aluminum foil, and transported to the nursery in a Styrofoam box with ice.

Rootstocks were prepared by cutting the shoot tip above the first node, making a Vshaped cut of about $3 \mathrm{~cm}$, and preserving lateral branches for photosynthetic activity. Scions were excised to a wedge shape (Figure 1A), and inserted into the rootstock. (Figure 1B). The junction was sealed with thread seal tape, and wrapped with parafilm (Parafilm American/Bemis), to prevent water loss and maintain cambium tissues in close contact (Figure 1C). Grafting was performed by a single experienced grafter.

Grafted plants were kept in a screened greenhouse with good aeration. New shoots were removed from the stock once a week to avoid competition with the scion.

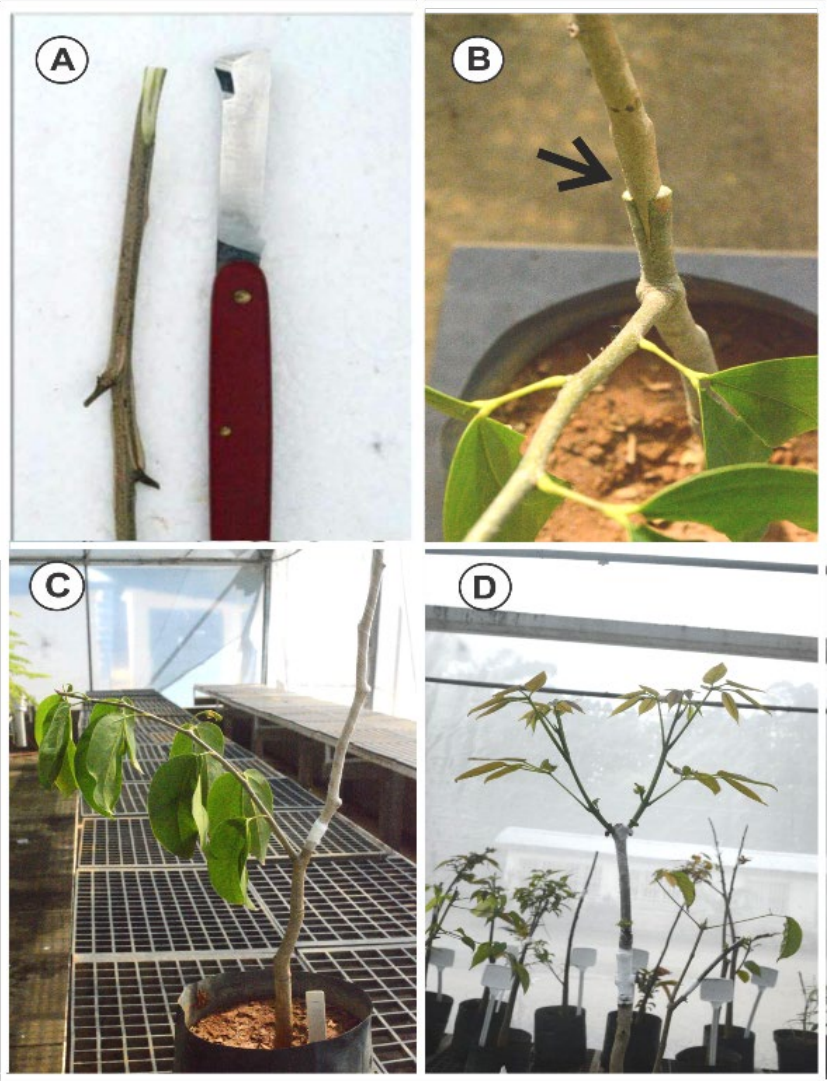

Figure 1. Representative photographs of (a) wedge-cut scion, (b) scion inserted into the rootstock (scion/stock junction indicated by an arrow), (c) graft treated with sealant and secured with parafilm, and (d) grafted plants inside a screened greenhouse.

\section{Experimental Design and Statistical Analysis}

The experiment was conducted in a completely randomized design with 40 replications per species, totaling 280 grafted plants. Graft survival and shoot number, length, and circumference were determined at 50 and 90 days after grafting (DAG). Data were subjected to analysis of variance (ANOVA) followed by Tukey's test $(P \leq 0.05)$ using the Genes software (Cruz, 2013).

\section{RESULTS AND DISCUSSION}

\section{Survival}

Graft survival at 50 and 90 DAG ranged from $7.5 \%$ (H. courbaril) to $82.5 \%$ (J. mimosifolia), differing significantly $(P<0.05)$ between species. The best results were observed for 
J. mimosifolia, H. heptaphyllus, S. terebinthifolius, and S. macrophylla, which exhibited survival rates above $65 \%$. Survival at 50 DAG did not differ from that at 90 DAG (Figure 2A and B).
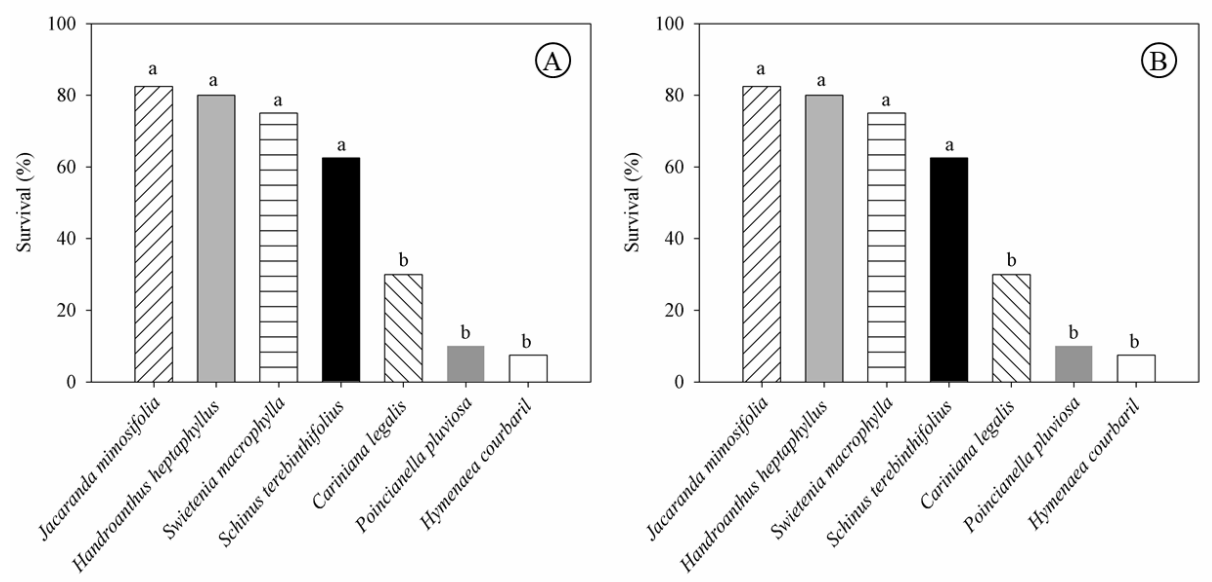

Figure 2. Survival of native tree species at 50 (a) and 90 (b) days after grafting. Means followed by the same letter do not differ significantly (Tukey's test, $P \leq 0.05$ ).

\section{Survival}

J. mimosifolia, H. heptaphyllus, S. terebinthifolius, and S. macrophylla grafts showed high survival rates (Figure 3 ). Plants were able to successfully adhere to the rootstock, form callus, and establish new vascular connections (Pina et al., 2012; Cachique et al., 2018).

The results agree with the survival rates of other native plants, such as yerba mate (Ilex paraguariensis A. St.-Hil.) (>57.8\%) (Wendling et al., 2009; Santin et al., 2015), Brazilian pine [Araucaria angustifolia (Bertol.) Kuntze] (69\%) (Wendling et al., 2016), and S. macrophylla (>48\%) (Barbosa Filho et al., 2016), and exotic species, including P. elliottii var. elliottii (72.6\%) (Medina Perez et al., 2007), E. dunnii (74\%), and E. urophylla $\times$ E. grandis (62\%) (Moraes et al., 2012).

Low graft survival was observed in C. estrellensis, P. pluviosa, and H. courbaril (Figure 2). It is likely that scion and rootstock were anatomically incompatible, precluding the formation of parenchyma and connection of vascular tissue (Flaishman et al., 2008). When this occurs, the flow of water, nutrients, and photoassimilates, as well as lignification of tissues, is impaired (Martínez-Ballesta et al., 2010; Almqvist, 2013; Souza et al., 2018; Nanda \& Melnyk 2018). Contact between cells is mediated by plasmodesmata, which allow symplastic transport of substances and metabolic interactions between stock and scion. This connection is necessary for subsequent differentiation of cambium and vascular tissues (Balbi et al., 2019). When plants are incompatible, these connections are not well established, resulting in low or no graft attachment.

Plants differ in morphological and physiological characteristics and, consequently, respond differently to different grafting techniques (Xavier et al., 2009; Leite et al., 2013; Gaspar et al., 2017). Grafting was performed during the summer, a period when plants direct their energy toward multiplying shoot cells rather than forming the constitutive and connective tissues needed for successful grafting (Zanette et al., 2011; Cassol et al., 2017). Future studies are needed to investigate the effects of grafting period and techniques on the survival of the studied species.

\section{Shoot length}

Shoot length at 50 DAE ranged from $4.48 \mathrm{~cm}$ (P. pluviosa) to $28.92 \mathrm{~cm}$ (C. estrellensis) (Figure 3A). At 90 DAE, shoot length ranged from $6.42 \mathrm{~cm}$ (P. pluviosa) to $42.72 \mathrm{~cm}$ 
(C. estrellensis) (Figure 3B). C. estrellensis differed significantly from other species both at 50 and 90 DAE.
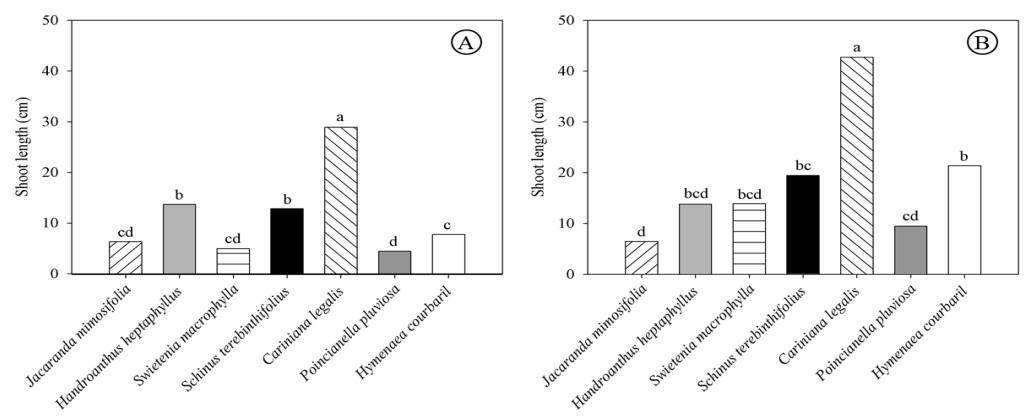

Figure 3. Shoot length of native tree species at 50 (a) and 90 (b) days after grafting. Means followed by the same letter do not differ significantly (Tukey's test, $P \leq 0.05$ ).

\section{Shoot length}

The differences in shoot length observed in this study are probably related to genetic and environmental factors (Franzon et al., 2010; Cassol et al., 2017) and to the grafting method used (Fernandes et al., 2008; Miao et al., 2019). Endogenous auxins play an important role in graft formation (Berleth \& Sachs, 2001). Regeneration and development of vascular tissues following injury are accompanied by migration of auxins within the plant (Mazur et al., 2016). The transcription levels of biosynthesis-related genes of this plant hormone are also altered in response to grafting. The translocation of auxin through cytoplasmic connections (plasmodesmata) favors graft attachment (Yu et al., 2017).

Previous reports showed that shoot length varies greatly with species. In A. angustifolia, shoot length ranged from 1.1 to $20.0 \mathrm{~cm}$ at 180 DAG (Constantino \& Zanette, 2018), whereas, in S. terebinthifolius, shoot length ranged from 0.5 to $3.5 \mathrm{~cm}$ at $45 \mathrm{DAG}$. This parameter can be influenced by grafting period and technique (Fernandes et al., 2008).

\section{Shoot circumference and number}

Shoot circumference ranged from $0.14 \mathrm{~cm}(P$. pluviosa) to $0.70 \mathrm{~cm}$ (S. macrophylla) at 50 DAG (Figure 4A) and from $0.23 \mathrm{~cm}$ (P. pluviosa) to 0.82 (S. macrophylla) at 90 DAG (Figure 4B). The shoot circumference of $S$. macrophylla was significantly higher than those of other trees. Shoot number differed significantly between species. The parameter was highest in S. terebinthifolius and C. estrellensis at 50 and 90 DAG (Figure 5).
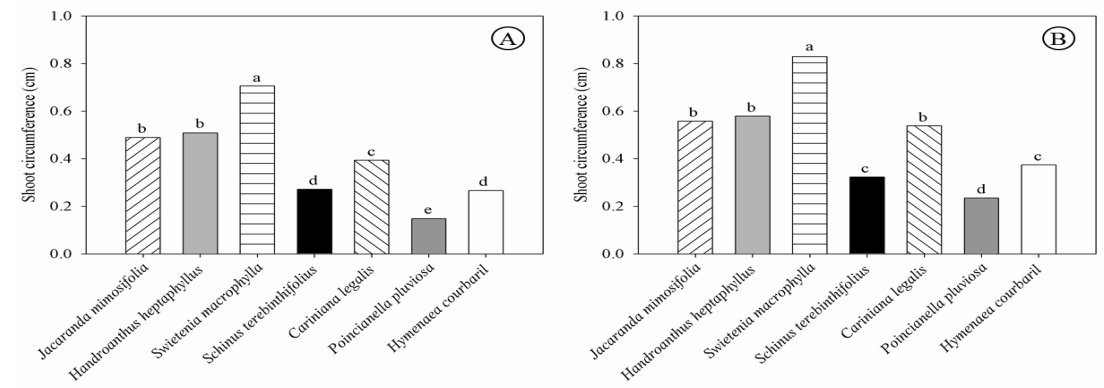

Figure 4. Shoot circumference of native tree species at 50 (a) and 90 (b) days after grafting. Means followed by the same letter do not differ significantly (Tukey's test, $P \leq 0.05$ ). 

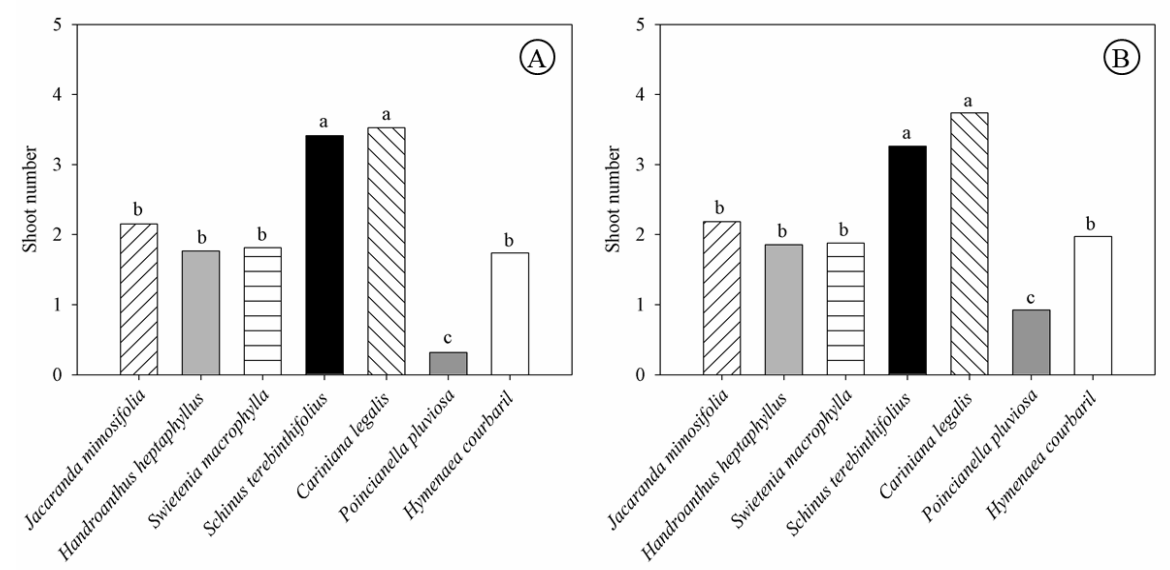

Figure 5. Shoot number of native tree species at 50 (a) and 90 (b) days after grafting. Means followed by the same letter do not differ significantly (Tukey's test, $P \leq 0.05$ ).

\section{Shoot circumference and number}

Shoot circumference possibly was influenced by genetic factors and by rootstock age, as observed in P. elliottii (Parker et al., 1998).

The physiological conditions of the rootstock and the propagation technique are major factors influencing graft vigor and shoot growth (Parker et al., 1998; Gaspar et al., 2017). In a previous study, S. terebinthifolius grafts produced by wedge grafting formed 2 to 3 new shoots (Fernandes et al., 2008), similar to the observed in the current study. The results indicate that the grafting technique was suitable for the evaluated tree species and can be used for their conservation and genetic improvement.

Vegetative propagation of native trees can contribute to the advancement of conservation and genetic improvement research. This low-cost technique allows for the conservation of alleles with good genetic diversity. By establishing clonal seed orchards, it is possible to combine divergent clones, increasing genetic variability for reforestation and ecosystem restoration programs. According to Vencovsky (1986), high genetic variability is required for conservation programs to be successful. To achieve such a variability, it is necessary to collect seeds from as many mother trees as possible, which greatly increases the cost of the process. Superior genotypes can be grown in pots in clonal seed orchards, thereby facilitating seed collection (Fajardo et al., 2018).

With grafting, the DNA of endangered species is conserved in a safe place (seed orchards), protected against unmanageable environmental factors or disasters. Several individuals (faithful DNA copies of a given mother plant) can be produced from a single specimen and returned to the forest area when the environmental risk has subsided.

Another advantage of grafting is attaining precocious flowering. Grafted plants can produce flowers and fruits in short periods, when plants are at lower heights, facilitating pollen management, natural and/or artificial pollination, seed production, and harvest.

Our results were efficient, yielding survival rates greater than $60 \%$ for most species at 50 and 90 days after grafting. In addition, we observed that the parameters used to evaluate the grafting efficiency were considered adequate. Sprout length greater than $10 \mathrm{~cm}$ and sprout circumference greater than $0.5 \mathrm{~cm}$ were observed in most species at 90 days. Furthermore, the number of shoots can be considered sufficient for the long-term maintenance and survival of the grafts.

For commercial purposes a higher percentage of survival is required than the ones achieved here, because a large-scale production of seedlings it is needed. However, the results obtained here, which fluctuate from about 10\% (Poincianella pluviosa and Hymenaea courbaril) to species that showed a survival rate close to $80 \%$ Vacaranda mimosifolia and Handroanthus heptaphyllus) are still relevant. These results allow the rescue of genetic material and the propagation of these native species 
Thus, we found that the technique proves to be efficient, in addition to being of low cost and are recommended for further studies with native Brazilian species.

\section{CONCLUSION}

The native tree species evaluated in this study were successfully grafted. J. mimosifolia, H. heptaphyllus, S. macrophylla, and S. terebinthifolius grafts had higher survival rates (60\% to $80 \%$ ) than C. estrellensis, P. pluviosa, and H. courbaril grafts, which fluctuate from $10 \%$ to $30 \%$ of survival.

Grafting can be used to establish clonal seed orchards, conserve endangered species and genetically improve native trees. Future studies should investigate the response of these species to the induction of early flowering and graft hybridization.

\section{ACKNOWLEDGMENTS}

The authors would like to thank the Universidade Federal de Viçosa, the Sociedade de Investigações Florestais (SIF) and Brazilian fund agencies Coordenação de Aperfeiçoamento de Pessoal de Nível Superior (CAPES) and Conselho Nacional de Desenvolvimento Científico e Tecnológico (CNPq) for their support to this research project. This study was financed in part by the Coordenação de Aperfeiçoamento de Pessoal de Nível Superior - Brasil (CAPES) Finance Code 001.

\section{REFERENCES}

Almqvist, C. (2013). Interstock effects on topgraft vitality and strobili production after topgrafting in Pinus sylvestris. Canadian Journal of Forest Research, 43(6), 584-588.

Balbi, R. V., Pio, R., Hora Farias, D., Melo, E. T., Pereira, M. P., \& Pereira, F. J. (2019). The cell regeneration and connection of grafting between pear and quince trees are defined by the cortex and phloem. Scientia Horticulturae, 257, 108662.

Bandeira, F. S., Xavier, A., Otoni, W. C., \& Dias, J. M. M. (2006). Enxertia in vitro na propagação de clones de Eucalyptus urophylla e E. grandis. Pesquisa Agropecuária Brasileira, 41(2), 223-232.

Barbosa Filho, J., Carvalho, M. A. D., Oliveira, L. S. D., Konzen, E. R., Campos, W. F., \& Brondani, G. E. (2016). Propagation of Khaya anthotheca: interspecific grafting with Swietenia macrophylla and air layering. Cerne, 22(4), 475-484.

Berleth, T., \& Sachs, T. (2001). Plant morphogenesis: long-distance coordination and local patterning. Current Opinion in Plant Biology, 4(1), 57-62.

Cachique, D. H., Solsol, H. R., Sanchez, M. A. G., López, L. A. A., \& Kodahl, N. (2018). Vegetative propagation of the underutilized oilseed crop sacha inchi (Plukenetia volubilis L.). Genetic Resources and Crop Evolution, 65(7), 2027-2036.

Cassol, D. A., Pirola, K., Dotto, M., Citadin, I., Mazaro, S. M., \& Wagner Júnior, A. (2017). Grafting technique and rootstock species for the propagation of Plinia cauliflora. Ciência Rural, 47(2), 1-6.

Constantino, V., \& Zanette, F. (2018). Enxertia de propágulos trunciformes nos ramos de Araucaria angustifolia e multiplicação de matrizes. Ciência Florestal, 28(2), 845-853.

Cruz, C. D. (2013). Genes: a software package for analysis in experimental statistics and quantitative genetics. Acta Scientiarum. Agronomy, 35(3), 271-276.

Fajardo, C. G., Costa, D. F. D., Chagas, K. P. T. D., \& Vieira, F. D. A. (2018). Genetic diversity in natural populations of Hancornia speciosa Gomes: implications for conservation of genetic resources. Ciência e Agrotecnologia, 42(6), 623-630.

Fernandes, K. H. P., Mori, E. S., Silva, M. R. D., \& Pinto, C. D. S. (2008). Propagação vegetativa de aroeirapimenteira (Schinus terebinthifolius Raddi). Revista Brasileira de Fruticultura, 30(3), 853-856.

Flaishman, M. A., Loginovsky, K., Golobowich, S., \& Lev-Yadun, S. (2008). Arabidopsis thaliana as a model system for graft union development in homografts and heterografts. Journal of Plant Growth Regulation, 27(3), 231-239.

Franzon, R. C., Gonçalves, R. D. S., Antunes, L. E. C., \& Raseira, M. D. C. B. (2010). Propagação vegetativa de genótipos de pitangueira (Eugenia uniflora L.) do sul do Brasil por enxertia de garfagem. Revista Brasileira de Fruticultura, 32(1), 262-267. 
Gaspar, R. G. B., Wendling, I., Stuepp, C. A., \& Angelo, A. C. (2017). Rootstock age and growth habit influence top grafting in Araucaria angustifolia. Cerne, 23(4), 465-471.

Gonçalves, P. D. S., Cardoso, M., Colombo, C. A., Ortolani, A. A., Martins, A. L. M., \& Santos, I. C. I. (1990). Variabilidade genética da produção anual da seringueira: estimativas de parâmetros genéticos e estudo de interação genótipo × ambiente. Bragantia, 49(2), 305-320.

Leite, G. A., Mendonça, V., de Medeiros Mendonça, L. F., Dantas, L. L. D. G. R., \& Cunha, P. S. (2013). Portaenxertos e métodos de enxertia na produção de mudas de Atemoieira (Annona squamosa L. $\mathrm{X}$ Annona cherimola Mill.). Semina: Ciências Agrárias, 34(5), 2117-2127.

Martínez-Ballesta, M. C., Alcaraz-López, C., Muries, B., Mota-Cadenas, C., \& Carvajal, M. (2010). Physiological aspects of rootstock-scion interactions. Scientia Horticulturae, 127(2), 112-118.

Mazur, E., Benková, E., \& Friml, J. (2016). Vascular cambium regeneration and vessel formation in wounded inflorescence stems of Arabidopsis. Scientific Reports, 6(1), 1-15.

Medina Perez, A. M., White, T. L., Huber, D. A., \& Martin, T. A. (2007). Graft survival and promotion of female and male strobili by topgrafting in a third-cycle slash pine (Pinus elliottii var. elliottii) breeding program. Canadian Journal of Forest Research, 37(7), 1244-1252.

Miao, L., Li, S., Bai, L., Anwar, A., Li, Y., He, C., \& Yu, X. (2019). Effect of grafting methods on physiological change of graft union formation in cucumber grafted onto bottle gourd rootstock. Scientia Horticulturae, 244, 249-256.

Moncur, M. W., \& Hasan, O. (1994). Floral induction in Eucalyptus nitens. Tree Physiology, 14(11), $1303-$ 1312.

Moraes, C. B., da Silva, P. H. M., Abílio, F. M., Pieroni, G. B., Gonçalves, A. N., \& Mori, E. S. (2012). Técnicas de enxertia: método modificado de enxertia em Eucalyptus. Série Técnica IPEF, 16(37), 25.

Morais, W. W. C., Susin, F., Vivian, M. A., \& Araújo, M. M. (2012). Influência da irrigação no crescimento de mudas de Schinus terebinthifolius. Pesquisa Florestal Brasileira, 32(69), 23-28.

Nanda, A. K., \& Melnyk, C. W. (2018). The role of plant hormones during grafting. Journal of Plant Research, 131(1), 49-58.

Parker, S. R., White, T. L., Hodge, G. R., \& Powell, G. L. (1998). The effects of scion maturation on growth and reproduction of grafted slash pine. New Forests, 15(3), 243-259.

Pina, A., Errea, P., \& Martens, H. J. (2012). Graft union formation and cell-to-cell communication via plasmodesmata in compatible and incompatible stem unions of Prunus spp. Scientia Horticulturae, 143, 144-150.

Pires, I. E., Resende, M. D. V., Silva, R. L., \& Resende Junior, M. F. R. (2011). Genética florestal (Vol. 1). Viçosa: Editora Arka; 2011.

Rocha, M. B., Rocha, D., Clemente, V. M., Freitas, M. V., Gomes, R., Jesus, S. V., Chaves, R. M., Torres, G. A., \& Xavier, A. P. (2002). Propagação vegetativa de espécies arbóreas nativas. In M. G. B. Rocha (Ed.), Melhoramento de espécies arbóreas nativas (pp. 91-108). Belo Horizonte: Diretoria de Desenvolvimento Florestal Sustentável, Instituto Estadual de Florestas.

Rouphael, Y., Schwarz, D., Krumbein, A., \& Colla, G. (2010). Impact of grafting on product quality of fruit vegetables. Scientia Horticulturae, 127(2), 172-179.

Santin, D., Wendling, I., Benedetti, E. L., \& Morandi, D. (2015). Nursery and field serial grafting of Ilex paraguariensis. Pesquisa Florestal Brasileira, 35, 409-418.

Souza, L. S., Diniz, R. P., Jesus Neves, R., Alves, A. A. C., \& Oliveira, E. J. (2018). Grafting as a strategy to increase flowering of cassava. Scientia Horticulturae, 240, 544-551.

Stuepp, C. A., Wendling, I., Xavier, A., \& Zuffellato-Ribas, K. C. (2018). Vegetative propagation and application of clonal forestry in Brazilian native tree species. Pesquisa Agropecuária Brasileira, 53(9), 985-1002.

Vencovsky, R. (1986). Tamanho efetivo populacional na coleta e preservação de germoplasma de especies alogamas (Boletim de Pesquisa e Desenvolvimento, No. 1, pp. 1-16). Brasília: Embrapa Recursos Genéticos e Biotecnologia.

Wendling, I., Lavoranti, O. J., Resende, M. D. V., \& Horrmann, H. A. (2009). Seleção de matrizes e tipo de propágulo na enxertia de substituição de copa em llex paraguariensis. Revista Árvore, 33(5), 811-819.

Wendling, I., Stuepp, C. A., \& Zuffellato-Ribas, K. C. (2016). Araucaria angustifolia grafting: techniques, environments and origin of propagation material. Bosque, 37(2), 285-293.

Xavier, A., Wendling, I., \& Silva, R. L. (2009). Silvicultura clonal: princípios e técnicas (2. ed.). Viçosa: Editora UFV. 
Yu, C., Dong, W., Zhan, Y., Huang, Z. A., Li, Z., Kim, I. S., \& Zhang, C. (2017). Genome-wide identification and expression analysis of CILAX, CIPIN and CIABCB genes families in Citrullus lanatus under various abiotic stresses and grafting. BMC Genetics, 18(1), 1-15.

Zanette, F., Oliveira, L. D. S., \& Biasi, L. A. (2011). Grafting of Araucaria angustifolia (Bertol.) Kuntze through the four seasons of the year. Revista Brasileira de Fruticultura, 33(4), 1364-1370.

Authors' contributions: GGCM: Data curation, Writing - original draft and Formal Analysis; GAS:

Conceptualization, Project administration, Funding acquisition and Supervision; AX: Methodology; SVM: Supervision; GAS: Writing - review \& editing; TGVM: Formal Analysis; RFRN: Data curation. 